\title{
The Development Trend of Modern Garden City and the Characteristic Town Construction
}

\author{
Shuai Yang \\ Zhuhai College of Jilin University, Zhuhai 519041, China \\ 26330587@qq.com
}

Keywords: garden city, characteristic town, modern city planning.

\begin{abstract}
Howard described the concept of the garden city from "Tomorrow: A Peaceful Path to Real Reform" written in 1898 for the first time, and explained ideological and theoretical structure of garden city, this theory is regarded as a relatively extremely sound ideological system in planning road of modern city. Planning theory of modern city is able to develop in this context; meanwhile the basic principles generated by garden city ideas occupy very critical position in the world's city development path. In the construction of Chinese cities, the combination of garden city theory more or less has an impact on the municipal researchers' city municipal construction concept, they will be become the direction of city design, and they are the basic requirements for the orderly operation of the city as well, call on the public and managers to focus on city planning, meanwhile when constructing city, prepare work in accordance with the full city planning, promote urban and rural progress, create an ecological balance system to achieve the goal of improving public equipment.
\end{abstract}

\section{Introduction}

Since the emergence of planning concept of garden city, the various regions and cities integrate theory with practice of garden city from a long time ago through a variety of forms, "garden city" as a concept, it shows a strong dynamic. For the practical content level, the focus is the construction of new district and urban evacuation design two parts. Howard pointed out that an effective measure is to create a new city in the suburbs of London for dealing with the congestion of London city traffic road at that time, namely, to create two garden cities, there are Letchworth and Welwyn, when modern cities are not affiliated with the realm of the old city, the practice of creating new city is its progressive positive innovation; in addition, the concept of garden city includes various satellite city construction and other new ideas, these ideas promote emergence of decentralized subject thinking mode of modern city construction, the aim is to create city with proper density for people. All the cities in China made full efforts to do comprehensive design for the urban green land in the period of the Republic of China; the origin of "new village construction" and other words are the new understanding of the planning concept of garden city, and a great breakthrough in this respect have been made.

\section{The Development Trend of Modern Garden City}

Because the current stage is a critical moment that ecological environment is under threat, respect for nature has become the basic norm that city construction and development must follow, in order to seek present economic interests, deliberate waste of natural resources and other problems need to be timely prevented, it is necessary to create environmental protection system for the public comfortable life in the city, and create a perfect ecological pattern with natural environment around the city, ecological harmony and natural health are ensured through this way, meanwhile creating favorable conditions for mankind creating sustainable development. And this view are fully shown in Howard's garden city planning theory, to ensure natural ecology, find and create perfect city that integrates advantages urban and rural areas, a city and township unity can promote human experience basis of city convenience, people can also feel infinite good scenery of nature and achieve the continuous supply of natural resources. 
In view of the theoretical research level, the significance of garden city the theory has been recognized and supported by various researchers all over the world, the garden city theory has been gradually throughout in the process of city design. For example, the garden city theory insists on principle of "people-oriented", "group gap type" city development theory, the construction theory of modern health city; the city construction based on the garden city theory, there are some theories to carry out empirical induction work, for example, construction idea of Chongqing garden city point out that the garden city rely on the current lower and natural forest green corridor, and then the city landscape and the rural scenery outside city become a complex, create a "city has fields, city in the field," garden city structure, Chengdu create "one strict, two belts, six corridors" international modern garden metropolis.

The developments of "modern garden city" are the future directions of modern city construction, so we should take the initiative to increase construction efforts of modern garden city, in addition to actively explore the new urbanization model. A city clearly recognizes history work it needs to do, clarifies the meaning and advantages and disadvantages of this city, and knows how the city should scale up, meanwhile point out the actual and scientific path by referring to practice. Xixian New District has been trying to actively explore and study China's modern garden city, prevent the city disordered expansion, resulting in long-term cooperation system; take the initiative to arrange flow direction of the elements of each side, the scientific requirements are gradually aggregated to the garden city, create an integrated design system; enhance the strategic cooperation within the city in the world, develop a rich cooperation model and study new urban and rural model of garden city. The focus of the creating garden cities is the new urbanization; the focus of new urbanization is to deal with rural and agricultural problems. "Modern garden city" is also the perfect way of life that mankind seeks. Enjoying the rural life is the future development direction modern urban residents who live in the concrete jungle. "modern garden city" inherit the original and the most traditional comfort for the people, open a new life outlook, the people who work and live in the city not only experience the globalized and high-quality modern city life, and can feel "green hills and blue waters, brilliant purples and reds pastoral poetic landscape. To create a new city with ecological comfort is the direction of urban development.

\section{The Construction of Characteristic Towns in Modern Garden City}

The "characteristics town" based on the garden city model, which mainly shows three characteristics, namely: beauty, characteristic and green. "Characteristic" is when creating town need to show individuality and the local traditional style, actual embodiment are in location, natural environment and so on. The so-called "green" is the fundamental purpose of building a small town is resource input and environmental harmony.

The towns with prominent characteristic are created based on the garden city model, cultivate the town brand imagination, town functions should be done a reasonable definition, and show a distinctive image town. There are a lot of small towns of western countries are world-famous, there are mainly the Koma town in France, Positano small town in Italy, the common characteristics that these towns have are: forests, countryside, rivers or lakes together create a natural ecological basis of small town, emphasizing development and retention of history and cultural traditions, the building structure mainly take enclosed building groups, the main line is the town square or teaching, together create a public, living communication environment, humane reception, to choose the material, color, small body fully show the town's environment, municipal and community complement each other and the function is complete, the town ease has produced a harmonious, comfortable living pattern. By contrast, China's small town development level is very slow, still no internationally known town image, but the various cities continue to explore at this stage develop some town development form worth reference and distinctive, the most famous is Chengdu "Five Golden Flower" build a modern agricultural base, develop farmhouse touring at scale, develop production companies, promote the employment and entrepreneurship of farmers, mean while creating a rich investment channels. 
Founding town with very architectural characteristics is paid attention to: integrated control, partial relaxation; their own characteristics are highlighted in the building structure design and other areas. It is necessary to combine the people and visitors' diversified production and living needs, and create a rich residential type. The traditional architectural style must be combined with the slope roof form; separate residential homes remember not to add housing, need to choose a transparent wall or hedge. The modern architectural style needs to be combined with the broken house or the flat house form, in addition to set-back model and balcony and diversified architectural appearance, the architectural color can be clearly distinctive; choose scientific materials such as wood and glass.

\section{References}

[1]. Ebenezer Howard, Garden Cities of To-morrow, The Commercial Press. (2010)

[2]. Yang Rui, On the Theory and Practice of Landscape Metropolis, Chinese Landscape Architecture. (2009)

[3]. Zhang Jingxiang, A Brief History of Western Urban Planning Thought, Southeast University Press or Southeast University Publishing House. (2005) 